\title{
A Typology of Corrupt Transactions \\ In Developing Countries
}

\author{
Mushtaq H. Khan \\ Sidney Sussex College, Cambridge CB2 3HU.
}

(This article was later published in IDS Bulletin (Liberalization and the New Corruption) 27 (2): 12-21)

Paper presented at Development Studies Association Annual Conference

Dublin, Ireland, September 1995

Draft not to be quoted. 


\section{SUMMARY}

Economic theory has attempted to identify the conditions under which corruption has particularly harmful effects. This paper evaluates these theories and argues that the classifications offered are misleading. These theories are important because very successful interventionist states have suffered from corruption just as much as very unsuccessful ones. Policy responses to corruption require an understanding of the effects of corruption and the determinants of these effects. The paper argues that the factor that appears to have a strong effect in determining the harmfulness of corruption is the balance of power between the state and its clients. An alternative classification of the effects of corruption is suggested.

\section{THE AUTHOR}

Mushtaq Khan is Assistant Director of Development Studies at the Department of Land Economy, University of Cambridge and Fellow and Lecturer in Economics at Sidney Sussex College, Cambridge. His research interests include the political economy of South Asia and institutional economics. 


\section{DEFINING CORRUPTION}

It is difficult to construct a definition of corruption that is not dependant on the moral or normative judgements of the observer. Indeed, it may not be desirable to do so. On the other hand, a definition of corruption that is clearly ethical is also subjective and a discussion of causes and consequences would require prior agreement amongst all participants about the relevant normative values. This is why corruption is usually defined in positive terms in most social science discussions. This usually involves defining corruption as a deviation from legal norms that are objectively observable, without questioning the morality or legitimacy of the legal norms themselves. This allows discussion to take place at the cost of ruling out some important activities that in an everyday sense would be identified as corrupt.

While the norm-based definition allows a clear identification of corruption, the identification can nevertheless be problematic. Legal norms change over time and vary across countries. What we require is an investigation of specific practices that have been identified as corrupt (Scott 1972). For example, if collusion of a particular type is a corrupt practice in one country but not another, we should not simply look at the effect of collusion in the first country. We should instead identify the effects of collusion across countries to identify its effects. Only in this way will we understand the implications of failing to enforce its prohibition in the first country. Fortunately, most of the types of corruption we are concerned with are illegal in most countries.

We are not concerned with illegal acts generally since corruption usually refers only to illegal decisions made by individuals in positions of public authority. A useful working definition of corruption based on this approach is widely used (Nye 1967). Corruption is defined as behaviour that deviates from the formal rules of conduct governing the actions of someone in a position of public authority because of 
private-regarding motives such as wealth, power or status. The goals of power and status are difficult to model, but it is relatively easy to model the economic effects of private wealth-seeking behaviour on the part of officials. This is the starting point for the economic analysis of corruption.

\section{SOME FACTS}

There is a strong perception amongst observers that corruption must have something to do with the lack of development in some countries. We would then expect either the scale of corruption to vary across good and bad performers or the types of corruption to vary across these countries. It is difficult to measure the scale of corruption with precision but it is clear that corruption is not limited to unsuccessful countries. Substantial corruption has been reported in Taiwan's public sector (Wade 1990). In late 1995, ex-president Roh Tae Woo of South Korea was arrested for corruption. He admitted accumulating a personal fortune of roughly 650 million dollars while in office. This is the first publicly acknowledged figure for corruption at the highest level in South Korea. Most observers believe this is the tip of a very large iceberg. While we may never be able to accurately compare the scale of corruption across countries, it is clear that it is difficult to attribute the much better performance of a South Korea or a Taiwan to the absence of corruption in these countries.

Nor is it possible to distinguish between countries in terms of the types of transactions that are subject to corruption. Bureaucrats in virtually every country have the power to allocate rights over scarce resources. This power is enhanced when the state plays an interventionist role in industrialization that is typical in most developing countries. Under these circumstances, it is not surprising that bureaucrats universally bargain for a share of the rents they help to create. Such rent-sharing corruption by bureaucrats in countries like Pakistan or Bangladesh is well known and 
has been the basis of a number of explanations of poor performance in such countries. However, similar practices are now known to have been commonplace in the NICs and in particular in South Korea.

The democratization of South Korea in the eighties has resulted in revelations of the extent of such transfers in the heyday of industrial policy. A major case, which came to the surface in the 1990s, was the decision of the Chun administration to disband the Kukje group chaebol (the Korean word for a large diversified holding company) when its chair refused to make appropriate transfers to President Chun's chosen funds. In 1993, a South Korean court found the Kukje breakup illegal opening the way for further cases to be brought and indicating finally a shift in the overwhelming power of the South Korean state. The Kukje case was the beginning of a series of revelations that culminated with the trial of Roh Tae Woo. Major chaebol such as Daewoo and Hyundai have now been implicated in massive transfers to state bureaucrats as a routine part of Korean industrial policy. Regardless of any moral judgements, these transfers did not lead to stagnation. On the contrary, the power of the South Korean state, which allowed it to impose transfers on industry, has also been very useful in allowing it to impose the performance criteria critical for the success of its industrial policy (Amsden 1989).

Rent-sharing by bureaucrats typically happens in the context of patron-client transactions. Patron-client transactions refer to a set of exchanges that overlap with corrupt transactions. Often the dominant relationship underlying corrupt transfers is a patron-client relationship between the state acting as patron and its clients, who are recipients of subsidies, licenses or other valuable resources. The state in its status of the patron is able to organize collusive transfers where officials can participate in a share of the resources being transferred to clients or in a share of the wealth that is 
eventually created because of the resource transfer.

Corruption in patron-client exchanges is usually thought to have negative consequences because it favours particularistic arrangements that fa vour specific clients. This results in allocative inefficiency because the most deserving recipients do not necessarily get access to public resources. This is the implicit argument in, for instance, Stanley Kochanek's (1993) description of patron-client relationships in government-business interactions in Bangladesh. In Kochanek's view, patron-client transactions play a major part in the explanation of economic backwardness in Bangladesh. While particularistic arrangements are not always corrupt, they usually involve transactions that are. For instance, the allocation of a public resource to favoured clients may not be illegal, but the kickback to the bureaucrat or politician almost invariably is.

However, patron-client relationships were also prevalent in dramatically successful countries. Once again, South Korea provides the countervailing evidence. The collusion between government and business in this country is now well documented. A small number of chaebol received very particularistic assistance in building up specialization in specific sectors. Production facilities were transferred across chaebol particularly in the eighties to achieve economies of scale and international competitiveness. Such patron-client contacts inevitably led to benefits flowing to companies close to the ruling regime with kickbacks to state officials and the president's party.

The evidence, such as it is, suggests that the problem is not the extent of corruption (though that may be a factor) nor even the kinds of transactions that are particularly subject to corruption. It suggests that we should instead try to identify more subtle 
differences in the types of corruption that can account for the differences in observed effects.

\section{CONVENTIONAL MODELS OF THE EFFECTS OF CORRUPTION}

The economic analysis of corruption aims to identify types of corruption in terms of their economic effects. The primary economic effect of corruption is an allocative one if as a result the final user of a resource is someone other than the one who would have had access to the resource otherwise. A secondary economic effect may be that in addition resources are lost in the process of corruption resulting in a decline in social output overall. Early economic models were interested in the first aspect of the problem but recently attention has shifted to the secondary effect in rent-seeking and transaction cost models.

\subsection{ALLOCATIVE EFFECTS.}

The allocative effect of corruption depends on a comparison of the output (or welfare) associated with the allocation that would have taken place without the corruption with the output (or welfare) associated with the allocation ex post. There are two possibilities. In the first the initial allocation is more efficient or welfare promoting than the subsequent allocation. Corruption here is clearly harmful. In the second, the post-corruption allocation is more efficient or welfare promoting than the initial allocation. In this case, corruption is actually beneficial.

To determine whether corruption in a particular case is harmful or beneficial we need information about

i) the initial allocation, given by the initial allocation of rights and the output or welfare associated with this,

ii) the ability of different classes of agents to demand the re-allocation or creation of 
rights. This determines the demand-side for corruption and tells us the effective demand for creating or re-allocating particular rights through corrupt transactions, and iii) the ability of state officials to change rights. This determines the supply-side of corruption by determining which rights can be re-allocated in response to corrupt transactions.

\subsection{CORROSIVE EFFECTS}

There are clearly effects of corrupt transactions that are over and above the allocative ones. The most obvious such effect is an increase in the instability of all property rights when corruption exceeds a critical level. Even when the initial structure of rights is such that corruption may be beneficial, too much corruption can lead to a loss of confidence in the institutional structure of society. The effect may be that social order breaks down totally, resulting in anarchy. This is the subject of game-theoretic models of social order but it is difficult to be precise about the level of corruption at which the corrosive effects outweigh any allocative effects. Most economic models concentrate on the allocative effects.

\section{MAINSTREAM ANALYSIS}

We can now identify the assumptions in mainstream approaches which analysts have used to reach particular conclusions. Corruption can enhance efficiency if the initial structure of rights was inefficient. But for corruption to actually have this effect, we also require that state bureaucrats are able to supply the changes in rights which increase efficiency and that these are also the changes which are demanded by wealthseeking agents in society.

Some of the early models of corruption, such as Leff's (1979) analysis of Sub-Saharan Africa, used such reasoning to conclude that corruption can have beneficial effects. 
The assumption was that the initial situation was characterized by competitionretarding restrictions that gave privileged profits to some people. Corruption opened up competition by persuading bureaucrats to create new rights enabling other suppliers to enter protected markets. However, it was patently clear that in many of the actual cases where corruption was observed, it would be hard to argue that corruption was having any positive effect at all.

It would be tempting to argue that in successful countries corruption transferred useful rights while in unsuccessful countries the rights transferred were restrictive and inefficient ones. In fact, we do not see systematic differences in the types of rights being purchased in dynamic as opposed to stagnant countries. We have seen in section 2 that in the most successful countries business interests have had to pay for allocations of subsidized credits, import licenses and tariffs just as in many of the least successful countries.

These similarities are due to the imperatives of late development that made most developing countries attempt variants of industrial policy. Developing country states have typically attempted to control access to credit, foreign exchange and other key inputs as part of industrialization strategies. For instance a comparison of industrial policy in South Korea and Pakistan in the 1960s shows that in both these countries the state was allocating subsidies while creaming off part of the benefits which these subsidies conferred on their recipients. The difference between the two industrial policy regimes was that while the South Korean state could impose performance criteria on its clients, the Pakistani state could not.

\subsection{THE DEMAND FOR RIGHTS}

Going beyond an examination of the rights transferred, conventional theory has 
looked at the effects of both the demand and supply structure of the market in rights. The first set of contributions came from rent-seeking theory that looked at the effects of different demand structures for rights. Instead of focussing on the effects of corruption on the allocation of rights, these theories focussed on the costs of organizing the re-allocation through corruption or otherwise. Consider the simplest case where corruption only results in a transfer. I had rights over a resource but because of corruption, these are transferred to you. If we value the resource identically, then as far as society is concerned, the transfer is costless because total output/welfare is unaffected. However, there is a cost to society if resources are used up in organizing the transfer: this is the rent-seeking cost. This is the cost of the resources used up in the process of bargaining, waiting and haggling and is quite distinct from the sums that are actually transferred because of corruption (Varian 1989). Nevertheless, the distinction between the size of the transfer and the rentseeking loss is frequently forgotten in the literature.

For this approach to explain the large differences in the effects of corruption across countries there would have to be substantial differences in rent-seeking costs across countries. The key variable identified in these theories, which explains the size of the rent-seeking loss, is the competitiveness of the political market. This determines the size of the resources used up in the process of bargaining. The assumption is that the cost individuals are willing to incur in rent-seeking activities depends on the probability of acquiring the right. However, the results of these models are generally indeterminate. Under some circumstances, greater competition can reduce the rentseeking loss. Under others, a restriction of competition has the same effect.

The contributions of Congleton (1980) and Rogerson (1982) are illustrative. Congleton compares democratic versus dictatorial re-allocations of rights and shows 
that whether democracy leads to greater competitive waste or not depends on the minimum bribes legislators are willing to accept. If the minimum effective bribes are very small, democracy can result in very small transfers. If the rent-seeking cost is proportional to the transfer, this means low rent-seeking costs. However, this result is overturned if the minimum effective bribe is very large, or, (a point which Congleton does not discuss) if legislators keep changing their minds in response to further offers. Thus, even in this simple model, while the degree of competition matters, the effect depends on exogenous factors including the bargaining power of legislators.

Rogerson in contrast argues that restricting the competition over rights to a few players can restrict the total transfers and by implication the rent-seeking loss. This result too depends on exogenous factors, in particular on whether the competition spills over into other sectors. For instance, the restriction of competition to a few players can result in an eventual political contestation of the legitimacy of the regime. If this were to happen, the rent-seeking cost with a few players could eventually be much higher than with a larger number of players. The low cost of rent-seeking in South Korea in the sixties could have more to do with society not contesting the legitimacy of the government-business networks rather than the number of chaebol competing for rights being small in number.

The theoretical indeterminacy of these demand side models is important because their results have sometimes been uncritically used. With relatively small changes in assumptions, these models can show that either democracy or authoritarianism is better at controlling rent-seeking costs. Even in their own terms, the results depend critically on exogenous factors, in particular the balance of power between the bargaining parties and the intensity of contestation by third parties not involved in the patron-client exchanges. 
Let us return to our comparison of South Korean and Pakistani industrial policy in the sixties. In both cases, the demand structure for key state subsidies was quite similar. A small number of industrial houses competed with each other for access to state subsidies. In South Korea, the strategy succeeded and the overall rent-seeking cost was low. In Pakistan, the strategy failed because players outside the restricted set of industrial houses could effectively make demands on the state and eventually brought down the regime. The cost of this secondary contestation was very large and was clearly part of the cost of allocating rights in this way. The important conclusion is that the social cost of a particular method of allocating rights cannot be read off from the competitiveness of the market for rights, as defined by the number of players in that market.

\subsection{THE SUPPLY OF RIGHTS}

A second group of theories examined the effects of different agency structures supplying new rights through corrupt transactions. Does the organization of the state matter in determining the size of corrupt transfers? The economic analysis of the structure of state agencies providing rights is one attempt to answer this question. This has been the approach of Shleifer and Vishny (1993).

State bureaucrats are assumed to provide a restricted supply of a useful range of rights (such as different licenses required to set up an industry). Shleifer and Vishny distinguish between three cases shown in figure 1 . The first is where the state is centralized and the single agency is the sole supplier of all the relevant rights. This is equivalent to the joint monopoly case in industrial organization. The state bureaucrats maximize their income from bribes by restricting the joint supply of the separate rights to their profit-maximizing level. 
The second case is one where a number of state agencies compete in the provision of complementary rights. Thus one agency may provide the right to import raw materials, another may provide the right to set up a factory, and a third may provide access to credit. If the different agencies are not centralized and independently try to maximize profits for themselves, each faces a prisoner's dilemma. In attempting to maximize its own rents, each may be raising the price of the particular right it supplies so high that overall activity shrinks and the total rent collected by all agencies falls.

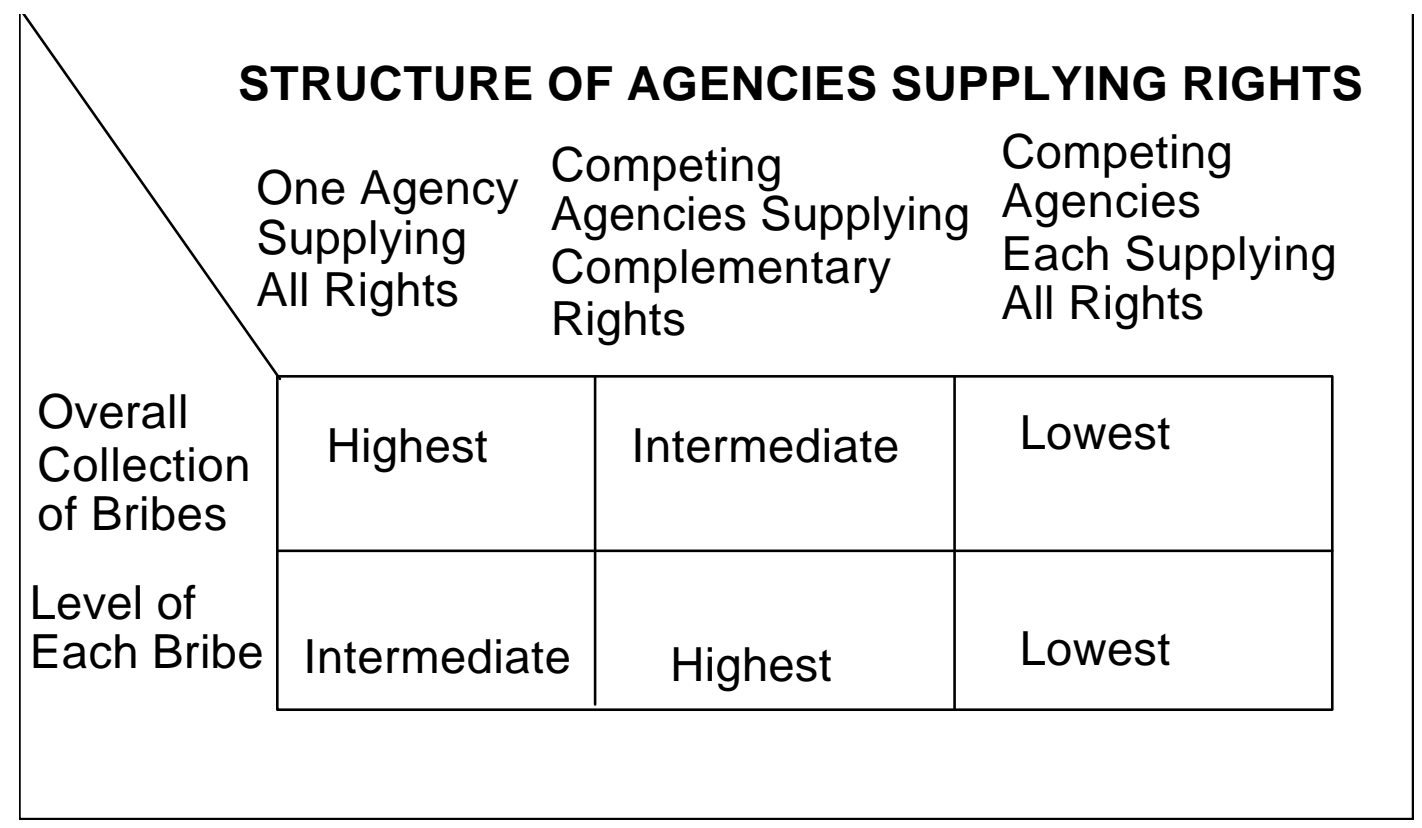

Figure 1. The Shleifer-Vishny Classification of Corruption

The final case is one where there are a number of agencies but they can each supply all the relevant rights. This is equivalent to a number of mini-states within the state, each competing for a share of the business. The outcome here is radically different. Each of the mini-states wishes to supply a package deal to purchasers with all the complementary rights necessary to set up the business. Competition between the ministates now has the very desirable theoretical result of pushing the price of the package 
of rights to zero and therefore total rents collected to zero as well.

The Shleifer-Vishny policy conclusion is straightforward. Increasing the competition amongst bureaucrats and allowing more agencies to supply similar rights is the best response to corruption. The aim is therefore to approximate the third column. The worst case is that of competing agencies supplying complementary inputs (column 2 in figure 1). Here the lack of coordination between agencies leads to a lower total rent being collected but only because the level of activity in the economy has shrunk. The absolute monopoly case (column 1) is marginally better. The bribe for each right sold is lower here, but the total bribe collected is higher because the economy operates at a higher level of activity.

The Shleifer-Vishny classification is useful for distinguishing extreme cases of state fracturing. When a large number of state agencies each monopolize some but not all the rights essential for economic activity we do have a transition to column 2 with its spiralling bribe levels and falling total bribe takes. However, does this distinction between agency structures account for the differences observed in the performance of corrupt developing countries?

The fragmentation of the state which column 2 describes is relevant for countries well on the way to anarchy. It requires subordinate state agencies to declare independence and to be able to enforce it. It is important to understand what this entails. It means that an agency such as the one providing industrial licenses can insist on a bribe level for these rights independently of other agencies and regardless of what happens to the aggregate level of economic activity. This is not the case with important rights even in weak states such as Pakistan or Bangladesh. 
The rights associated with important projects requiring the permission of a number of agencies are typically transacted at a high enough level of the state to encompass the complementary agencies. Indeed some of the worst performing cases such as Haiti under Duvalier, Bangladesh under Ershad or the Philippines under Marcos are closer to the monopoly case in column 1 of figure 1 rather than column 2 . The big leader has a hand in every pot and clearly has an interest in maximizing the total rent collected.

On the other hand, some of the most successful countries do not correspond to the competitive supply case of column 3 but are also closer to column 1 . Shleifer and Vishny admit that the Korean state approximates to the monopolistic model and find it puzzling that it has not suffered the same fate as other monopolistic suppliers. Clearly there are some differences in the organizational structure of the state bureaucracy supplying rights across countries and these supply side features can explain part of the difference in the effects of corruption between them. However, most organizational structures relevant for the supply of rights through corruption are located between the monopolistic and oligopolistic cases summarized in columns 1 and 2 in figure 1 . The differences between them (while they may still be quite important) do not appear to be big enough to explain the dramatic differences between a Haiti and a Taiwan or a South Korea and a Bangladesh.

\section{THE POLITICAL SETTLEMENT, CLIENTELISM AND CORRUPTION}

The weakness of conventional economic models of corruption is that the context of political power in which corruption takes place is not explicitly analysed. The balance of power between state agencies and different classes of agents is an important determinant of the effects of the bargain between state bureaucrats and their clients. The balance of power determines what is demanded, by whom and on what terms. It also determines the feasible responses of the state to such demands, given the 
structure of supply. We will refer to a particular balance of power as a political settlement.

Conventional models assume that a structure of well-defined rights exists and that the bargaining between state and society takes place based on these rights. Corruption is therefore seen as an essentially economic phenomenon where rights are transferred to the agents who value them the most, given a pre-existing distribution of economic resources. Implicit in the assumption of well-defined rights is an assumption about the political settlement. It is assumed that the state is an effective state when it comes to the protection of existing rights.

This is assumed even in the Shleifer-Vishny model with competing state agencies supplying complementary rights. The state may have disintegrated as a centralized entity but it is still assumed that each segment of the state is selling well-defined rights. The power of the state vis-a-vis society in defining rights in general is not in question. The assumption that the state can protect well-defined property rights is a simplification that prevents a useful analysis of the effects of corruption. The political settlement in most developing countries is far removed from the idealtype implicitly assumed in standard neoclassical economic theory.

In varying degrees, the actual political settlement in most developing countries places the state in a relatively weak position as far as the protection and enforcement of property rights is concerned. Typically, there are continuous political challenges coming from excluded sections of society contesting the existing allocation of rights. The state is usually only partially capable of effectively protecting existing rights. The economic bargains between the state as patron and its clients, which are sometimes but not always corrupt, take place in this context. Our argument (Khan forthcoming) 
is that the outcomes of these economic transactions depend on the context of political contestation in which the economic transactions are negotiated.

Looking at the balance of power between the state and its clients, at one extreme would be the conventional patron-client model. Here the state as patron is the politically dominant partner and dispenses resources to clients to get a share of the rent or simply additional political support. In practice, the balance of power between patron and client is often tilted the other way in post-colonial developing countries. States often lack legitimacy and face perpetual challenges from politically powerful and well organized social groups. Here clients, or rather the social groups from which particular clients are drawn, are relatively much more powerful than in the first case and can extract much better bargains from the state.

To distinguish between the two types of patron-client relationships, we identify two ideal-types. We call the power balance underlying the conventional patron-client relationship a patrimonial political settlement. In contrast, we call the political settlement where clients are relatively more powerful a clientelist political settlement. The characteristic feature of the clientelist political settlement is that the property rights defined by the state are weakly-defined and are contested by wellorganized social groups who are able to challenge the rights being enforced by the state. This political settlement is typical of many post-colonial countries.

A characteristic feature of the clientelist political settlement is that in the face of such contestation, agents granted rights by the state have to make payoffs to other clients (often through the mediation of the state) to continue to have access to the incomes generated by their assets. Examples of such payoffs include employment generation for organizationally powerful groups, bribes to lower level functionaries whose power 
lies in the ability to contest rather than deliver, payoffs to local mafias and so on.

\subsection{THE POLITICAL SETTLEMENT AND THE STRUCTURE OF DEMAND}

The patrimonial political settlement corresponds to the assumptions in conventional economic models of corruption. The state has the power to protect rights and to reallocate them at a price. The (indeterminate) results summarized earlier from conventional rent-seeking and agency structure models are relevant for this case.

Under a clientelist political settlement, the bargaining problem changes. We now have a situation where groups of clients can politically contest rights and depending on the effectiveness of their political organization, bureaucrats are likely to give them preferential "prices" for the rights they require. Compared to the patrimonial political settlement, the preferential allocation of rights to politically powerful clients amounts to a payoff that the clientelist coalition gets from the state. Thus in this situation the terms of the economic bargain, whether corrupt or not, will depend on the distribution of political power and the exposure of the state to clientelist contestation.

What this means is that the transfer or creation of rights will not simply be in response to the economic price clients are able to pay but also on their relative political power. Shifts in the balance of power can now affect the efficiency of economic transactions between the state and its clients. In Pakistan and Bangladesh, these exogenous shifts in the power balance correlate quite well with changes in the observed efficiency of the rights created through state intervention (Khan forthcoming).

Thus in the clientelist political settlement, the effective demand for rights is determined not just by the distribution of purchasing power but also by the distribution of political power. The effects of corruption are therefore specific to the 
particular distribution of power between the state and competing groups of potential clients. This makes it possible for apparently similar corrupt transactions to have very different effects in different countries.

\section{2 THE POLITICAL SETTLEMENT AND THE SUPPLY OF CORRUPTION}

The clientelist political settlement also has implications for the supply of rights. Another consequence of a power balance favouring clients is that while it may be relatively easy to create new rights, it is very difficult to change or transfer existing rights in ways which hurt powerful constituencies. If the state is politically weak to start with, it is not likely to do anything that reduces its political viability further. The existing rights of clients are likely to have been negotiated in the past based on political power. Unless this power has diminished, the transfer of rights, even if another agent is willing to pay heavily for it, will have to be considered in terms of political costs and benefits for the state. This means that even when some agents are willing to bribe to change the structure of rights, the state may be politically unwilling to consider reallocations of rights. This does not happen in the patrimonial political settlement or in the models considered in conventional economics.

If existing rights cannot be changed except at great political cost, the state may prefer to create new rights. The proliferation of new rights may indicate disarticulated state machinery as in the Shleifer-Vishny classification of competing state agencies providing complementary rights (column 2 figure 1). But here the causality behind the proliferation is quite different.

The proliferation does not happen because the organizational structure of the state is fragmented, preventing potential coordination amongst state agencies. In fact, in many countries with corrupt leadership, the supreme leader is nominally in a 
monopolistic position. He usually takes a cut from all agencies and is aware of the major projects that are going on. Instead, the proliferation happens because it is politically impossible to make the monopoly effective, as this would override the interests of powerful sets of clients. If too many clientelist coalitions were affected, their political opposition would seriously threaten the political viability of the state.

Thus under a clientelist political settlement we would see a proliferation of rights as new rights are created rather than existing ones being re-allocated. This is quite different from the scenario in column 2 of figure 1 where we see a proliferation of agencies that results in the price of rights being driven up. The proliferation of rights has important economic implications such as excessive entry into protected industries, excessive employment creation for white collar workers and so on.

\subsection{AN ALTERNATIVE TYPOLOGY OF CORRUPT TRANSACTIONS}

The summary of the effects of the political settlement presented above suggests that the effects of corruption will depend on the balance of power under which such transactions are carried out. Figure 2 shows an alternative classification that distinguishes between patrimonial and clientelist political settlements. This classification suggests that the results of conventional models are valid if at all for a particular balance of power between the state and its clients. It requires a political settlement that allows the state to protect well-defined rights in the conventional way. We have termed this the patrimonial political settlement. 


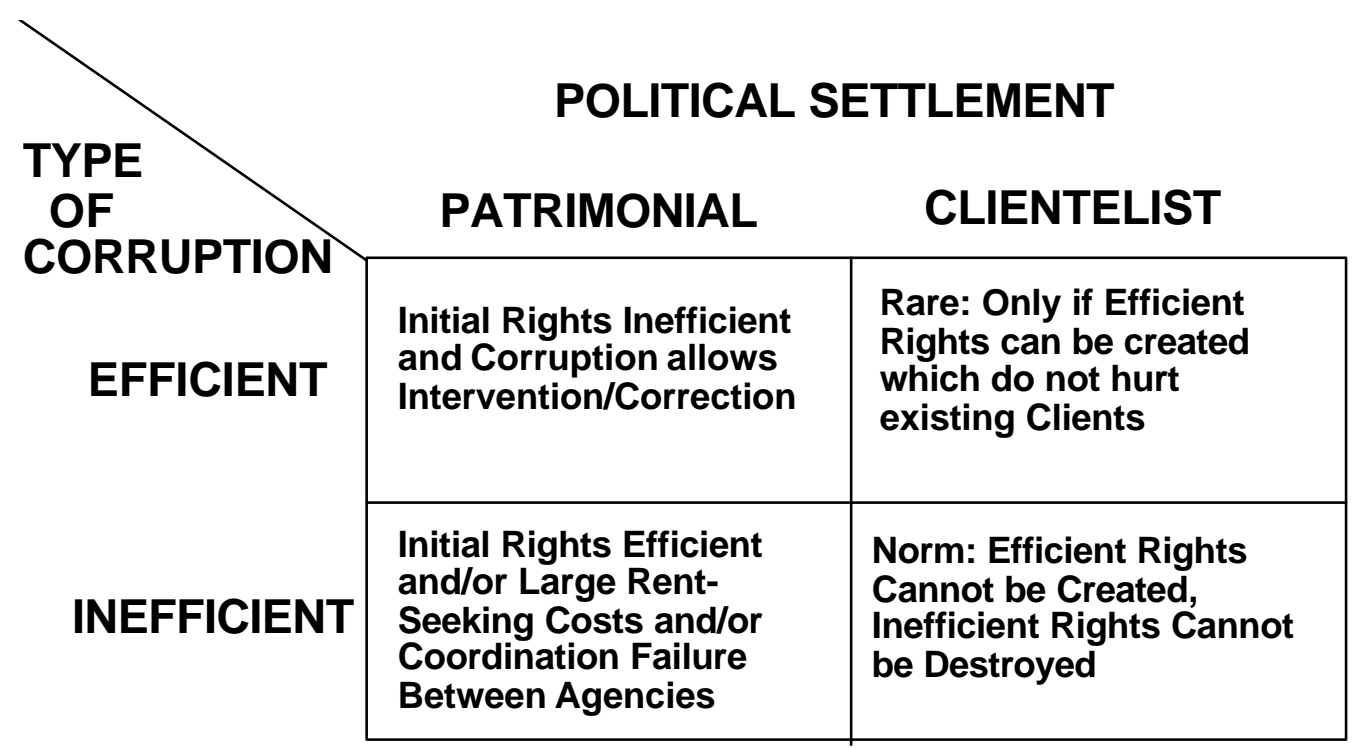

Figure 2. A Classification of Corruption under Different Political Settlements

In contrast, the clientelist political settlement is characterized by weakly-defined rights and here the relative political power of clients matters in determining the payoffs they get from the state. Corrupt transactions in this context are likely to lead to the failure of rights being re-allocated even when this is socially desirable and even if this would be economically beneficial to state officials in the sense of maximizing their bribes. We would also expect the clientelist political settlement to lead to a proliferation of rights that may also be inefficient.

The political economy informing the support of liberalization as a means of dealing with corruption and its associated social losses can be assessed in the light of our discussion. Liberalization will succeed in lowering the social costs associated with corruption if the costs of corruption are due to inadequate competition for rents on the demand side or inadequate competition between self- sufficient agencies on the supply side. The demand-side argument is based on contingent assumptions in rent-seeking theories. The supply-side argument is even weaker and the ideal type shown in column 3 of figure 1 is an unrealistic portrayal of the actual experience of successful 
developers.

If the problem of inefficiency associated with corruption is due to the operation of corruption in a clientelist political settlement, liberalization may have little effect in reducing inefficiency. The contestation of the state's legitimacy will not necessarily decrease simply because the state declares itself to be negotiating the supply of fewer rights. The evidence of liberalization in developing countries suggests two possible outcomes. If political opposition to liberalization is very strong, it is likely to be implemented partially and in an ad hoc manner as has happened in the Indian subcontinent. Alternatively, the contestation over rights can become truly anarchic with local mafias enforcing rights for politically powerful groups in return for large payoffs. In either case, an improvement in efficiency is unlikely to occur.

\section{REFERENCES}

Amsden, A. 1989. Asia's Next Giant. Oxford: Oxford University Press.

Congleton, R. 1980. Competitive Process, Competitive Waste, and Institutions in J. Buchanan, R. D. Tollison and G. Tullock (eds), Towards a Theory of the RentSeeking Society. College Station: Texas A\&M University Press.

Khan, M. H. (forthcoming) Clientelism, Corruption and Capitalist Development. Oxford: Oxford University Press.

Kochanek, S. A. 1993. Patron-Client Politics and Business in Bangladesh. New Delhi: Sage. 
Leff, N. 1979. Economic Development through Bureaucratic Corruption, in M. U. Ekpo (ed), Bureaucratic Corruption in Sub-Saharan Africa: Toward a Search for Causes and Consequences. Washington: University Press of America.

Nye, J. S. 1967. Corruption and Political Development: A Cost-Benefit Analysis, American Political Science Review, Vol LXI, No 2.

Rogerson, W. P. 1982. The Social Costs of Monopoly and Regulation: A Game Theoretic Analysis, Bell Journal of Economics, Vol 13.

Scott, J. C. 1972. Comparative Political Corruption New Jersey: Prentice Hall.

Shleifer, A. and Vishny, R. W. 1993. Corruption, Quarterly Journal of Economics, Vol 108 No 3.

Wade, R. 1990. Governing the Market: Economic Theory and the Role of Government in East Asian Industrialization. Princeton: Princeton University Press.

Varian, H. 1989. Measuring the Deadweight Costs of DUP and Rent Seeking Activities, Economics and Politics Vol 1 No 1.

MK/26 December 1995/"a:corrupt.khn" 